\title{
Defining project success ${ }^{1}$
}

\author{
H. Kerzner \\ Business Administration, Balwin-Wallace College, Ohio \\ V. Ghyoot \\ Department of Business Economics, University of South Africa, Pretoria
}

The authors explain why an understanding of the meaning of success is crucial to the achievement of project success; examine the definitions of project success found in the literature and make some suggestions regarding the meaning of project success.

S. Afr. J. Bus. Mgmt. 14: $102-104$

Die outeurs verduidelik waarom 'n begrip van die betekenis van sukses noodsaaklik is vir die bereiking van projeksukses; ontleed die definisies van projeksukses in die literatuur en maak 'n paar voorstelle oor die betekenis van projeksukses. S.Afr. Tydskr. Bedryfsl. 1983, 14: 102-104

\section{Prof. H. Kerzner}

Business Administration, Balwin-Wallace College, Ohio, USA V. Ghyoot*

Department of Business Economics, University of South Africa, P.O. Box 392, Pretoria 0001, Republic of South Africa

*To whom correspondence should be addressed
Project success is probably the least understood and researched aspect of project management. Yet it is undeniably the most important. No project will ever be undertaken unless there is some chance of it being successful.

In this article the authors explore the need for a definition of success; discuss success as defined in the literature and make some suggestions regarding the meaning of success.

\section{Why define project success?}

R \& D projects, MIS projects and O.R. projects are characterized by the fact that they continuously generate sub-projects, some of which are pursued concurrently with the main project. In a recent case, the following question arose: In an environment where short-term objectives are constantly shifting, how does one measure progress if successful completion of each sub-project has not been defined?

Rolefson has stressed the importance of a recognized end point to a project and an evaluation of the performance of the project team after the project has been terminated. ${ }^{2}$ But when does a project end if successful completion has not been defined, and against which parameters does one evaluate the project team?

DeCotiis, Dyer and Hundert observe that a large measure of the discrepancy between the theory of project management and its successful application in practice may be ascribed to the fact that the meaning of project success is not clearly defined or understood. A manager may know that a given project was successful, but would be unable to explain why he considers it a success. ${ }^{3}$

In a study of the determinants of project success, Murphy, Baker and Fisher found that the degree of clarity and consensus concerning the meaning of success was one of the seven variables which, together, explained $91 \%$ of the success of a project. ${ }^{4}$

\section{Project success as defined in the literature}

In defining success, it is important to distinguish between various types of projects. The success of a motion picture, for example, may be measured in terms of the profit it makes or the number of awards it generates; but how does one measure the results of the space shuttle programme? The dimensions of success are therefore unique to every type of project, and sometimes unique to every individual project.

Success also has a different meaning to various people associated with the project. ${ }^{5}$ The project engineer may view 
success as an end-product which performs perfectly, while an accountant may view success in terms of the lowest possible expenditure on the project. The project manager, on the other hand, could interpret success as the timeous delivery of a product which conforms to the minimum standard specified, with costs as close to the budget as possible.

For various types of projects, the traditional view is that a project is successful if it meets the time, cost and quality (performance) goals set for it at its inception. ${ }^{6}$ Taylor and Watling warn that in using these dimensions of success one presupposes that:

- the original project evaluation was sound; and

- the project aim was sound. ${ }^{7}$

These two qualifications raise serious doubts as to the validity of using time, cost and quality as parameters of project success. Taylor and Watling mention the Sydney Opera House as an illustration of why project success is not such a simple matter. The project was completed ten years behind schedule and greatly exceeded the original budgeted cost, yet who is to say that the project was a failure? Sydney now possesses a magnificent opera house in a beautiful setting.

Avots implies the inadequacy of time, cost and quality as dimensions of success by adding that a project should also achieve any other objectives which were set for it. ${ }^{8}$ This extra dimension indicates that a project may also have to achieve goals which are not as clearly definable or as measurable as time, cost and quality, and which may be unique to the particular project under consideration. Bennigson states that it is possible to have dissatisfied customers even though time, cost and performance criteria have been met. ${ }^{9}$ Accordingly, he identifies customer satisfaction as a further dimension of project success. Bennigson also identifies three further parameters by which success may be gauged, namely:

- The amount of follow-on work that is generated by the project.

- The internal spinoff caused by the project.

- The magnitude of the change brought about by the project.

These last three parameters identified by Bennigson fall into the category of individual project success dimensions and are not applicable to all projects.

With regard to management information system projects, the following dimensions of success were identified in a study undertaken by Powers and Dickson: ${ }^{10}$

- Time

- Cost

- User satisfaction

- The efficiency of computer operations.

Even though the study of Powers and Dickson was confined to management information system projects, its results support the general view of Bennigson, namely that client satisfaction is probably the most important dimension of project success. Of twenty MIS projects studied, $70 \%$ were behind schedule and $90 \%$ exceeded budgeted cost. Nevertheless, most users were happy with their system.

The importance of less clearly defined and measurable parameters of success was recognized by Murphy et al in a study undertaken for the National Aeronautics and Space Administration and published in 1974. The study concerned non-NASA projects. In the questionnaire, success was measured by the following items:

- All things considered, the project was a success.

- The satisfaction of the following groups with the out- come of the project:

- parent organization,

- client organization,

- ultimate users,

- project team.

- The extent to which the end result fulfilled the technical performance mission or function.

It is interesting to note that the first item above proved to be an adequate measure of success. Time and cost were not considered to be dimensions of success by the companies surveyed - in particular, Murphy found no statistical relationship between projects that were considered successful and their cost performance. Successful projects more often than not tended to show a cost overrun. These results support the warning of Taylor and Watling, namely that time, cost and performance may only be used as dimensions of project success providing the original project evaluation and aim were sound.

The emphasis Murphy et al placed on the intangible measures of project success was found unsuitable by DeCotiis and Dyer when studying research and development projects in a matrix environment. Their conclusions were published in 1977. ${ }^{11}$ DeCotiis and Dyer observed that a manager may know that a project was successful but have no understanding of the alchemy of project performance and would therefore not learn from the experience.

Accordingly, they undertook a pilot study in order to define the dimensions of project success in an unambiguous manner. The following five dimensions were identified:

- Manufacturability and business performance of the end product;

- Technical performance of the end product;

- Efficiency of project operations;

- Personal growth experience of the project team; and

- Technical innovativeness.

The first three dimensions identified by DeCotiis and Dyer indicate how perception of the basic time, cost and quality parameters have changed with the passing of time.

DeCotiis and Dyer suggest that the first dimension, manufacturability and business performance, is the ultimate criterion of research and development project success. This implies that the end product must:

- be manufacturable;

- enter the market at the correct time; and

- realize a profit;

if the project is to be considered successful.

In a study of research and development projects in 1976, Rubenstein $e t$ al implied the same conclusion as DeCotiis and Dyer by defining success in relation to two dimensions, the second of which is equated to overall project success: ${ }^{12}$

- Technical success;

- Economic or project success.

De Cotiis and Dyer, and Rubenstein $e t$ al are the only authors found who include profit in their definition of success.

\section{Suggestions concerning the meaning of project success}

The findings discussed in the previous section relate to different types of projects, but some general remarks concerning the meaning of project success are possible:

- The case of the Sydney Opera House and the independent research of Powers and Dickson, and Murphy et $a l$, show that the only basic parameter of success which 
is generally valid, is performance (quality). Time and cost are secondary, and are usually judged in relation to performance.

- The research by Murphy also shows that some measures of success are intangible - for example, the satisfaction of participants with the project's outcome.

- In general, authors agree that success is multidimensional. A project could therefore be a failure in some respects, whilst at the same time being a success in other respects.

- Silverman has pointed out that success has a different meaning to various people associated with the project. The authors suggest that:

- No single author adequately defines success. DeCotiis, Dyer and Hundert point out that a vague definition of project success contributes to project failure.

- Some measures of a project's success are unique to the given project. If the overall goal and the most crucial objectives of a project are attained, the project is a success.

- Projects should be viewed in a broader economic sense. Success should thus be measured in terms of the benefits obtained by each party involved in a project. These benefits could include profit or an end product.

When viewed in this light, it becomes clear why projects that are behind schedule or exceed their budgets are frequently still considered a success - the benefits derived from the end product, or the profit realized, compensate for cost and schedule overruns.

It is clear that the meaning of success is unique to each type of project and that there is no simple formula for defining project success. It is nevertheless possible to do so. Precisely what constitutes success should be defined for every project during its conceptual planning stage. If this is done, the project team will be in a position to constantly monitor progress towards the overall project goal.

\section{References}

1. This article is based in part on Ghyoot, V.G. Success as a Goal in the Training of Project Managers, Unpublished M.Com. dissertation, University of South Africa: Pretoria, 1981.

2. Rolefson, J.F. Project Management - Six Critical Steps. J. Syst. Manage. April 1978, p.10.

3. DeCotiis, T.A., Dyer, L. \& Hundert, A.T. The Nature of Project Leader Behaviour and its Impact on Major Dimensions of Project Performance, p. 30. Paper presented at the Project Management Institute seminar, 1976.

4. Murphy, D.C., Baker, B.N. \& Fisher, D. Determinants of Project Success. National Aeronautics and Space Administration, 1974.

5. Silverman, M. Project Management, Part One: Project vs. Functional Management, p. 6. Wiley Professional Development Programme. New York: John Wiley \& Sons, 1976.

6. See for example Anthony, E.F., Kustara, J.J. \& Shaver, H.L. Rating Project Performance by Time-Cost-Quality. Paper presented at the ISA Conference, 1977.

7. Taylor, W.J. \& Watling. T.F. Practical Project Management, p. 161. London: Business Books, 1973.

8. Avots, I. Why does Project Management Fail? Calif. Manage. Rev. Vol. 12, No. 1, Fall 1969, p.77.

9. Bennigson, L. The Strategy of Running Temporary Projects. Innovation, Sept. 1971, p.32.

10. Powers, R.F. \& Dickson, G.W. Misproject Management: Myths Opinions and Reality, Calif. Manage. Rev. Vol. 15, No. 3, Spring 1973, p.147.

11. DeCotiis, T.A. \& Dyer, L. The Dimensions and Determinants of Project Performance, Ind. Market. Manage. Vol. 6, 1977, p.370.

12. Rubenstein, A.H., Chakrabarti, A.K., O'Keefe, R.D., Souder, W.E. \& Young, H.C. Factors Influencing Innovation Success at the Project Level, Res. Manage. May 1976, p.15. 